\title{
Distribution of meroplankton communities in the Bransfield Strait, Antarctica
}

\author{
E. Vázquez ${ }^{1, *}$, J. Ameneiro ${ }^{1}$, S. Putzeys ${ }^{2}$, C. Gordo ${ }^{3}$, P. Sangrà ${ }^{3}$ \\ ${ }^{1}$ Dpt. Ecoloxía e Bioloxía Animal, Facultade de Ciencias do Mar, Universidade de Vigo, 36200 Vigo, Spain \\ ${ }^{2}$ Dpt. Biología and ${ }^{3}$ Dpt. Fisica, Facultad de Ciencias del Mar, Universidad de Las Palmas de Gran Canaria, \\ 35017 Las Palmas de Gran Canaria, Spain
}

\begin{abstract}
The spatial distribution of meroplankton in Bransfield Strait, Antarctica, and its relationships with hydrographical conditions are described. Biological sampling was carried out with BIONESS sampling gear at 19 stations and at 5 depths between 10 and $300 \mathrm{~m}$. The main hydrographic features were a shallow hydrographic front in the southern part of the strait that separates Transitional Zonal Water with Bellingshausen influence (TBW) from Transitional Zonal Water with Weddell influence (TWW) and a slope front, the so-called Bransfield front, along the South Shetland Islands Slope (SSI). A northeastward baroclinic jet known as the Bransfield Current (BC) originates from this slope front. The meroplankton community was very diverse and included 12 types of larvae, dominated by polychaete and echinoderm larvae. The meroplankton were more abundant closer to the SSI in the BC and decreased in number towards the Antarctic Peninsula. Polychaete larvae were found close to both shores but mainly close to the SSI in TBW; they were very sparse in the central basin, appeared again below $100 \mathrm{~m}$ depth in TWW, and increased in abundance in upper layers at stations between the hydrographic front and the Antarctic Peninsula, in TWW. By contrast, echinoderm larvae mainly occupied the central basin and were always associated with the upper $100 \mathrm{~m}$ in TBW, just above the polychaete larvae; they were almost absent from TWW. In summary, meroplanktonic larval exhibit a strong dependence on water masses, depth, and fronts.
\end{abstract}

KEY WORDS: Meroplankton - Bransfield Strait - Antarctica $\cdot$ Invertebrate larvae $\cdot$ Distribution · Hydrography

\section{INTRODUCTION}

Different views of Antarctic marine invertebrate biology have been proposed since the end of the 19th century (reviewed in Arntz \& Gili 2001). It was believed that Antarctic marine invertebrates developed adaptations in response to low temperatures and strong seasonality in an area where primary production is reduced to a short period during the austral summer. Low metabolic rate, slow growth rate, longevity and gigantism were among the strategies proposed. In terms of reproduction, strong seasonality with delayed first maturity, low fecundity, large eggs and nonpelagic larval development were considered as adapta- tions to Antarctic environmental conditions (Arntz \& Gili 2001, Poulin et al. 2002). However recent studies of Antarctic meroplankton have revealed a relatively high diversity and abundance of larval forms of benthic marine invertebrates (Arntz \& Gili 2001, Sewell 2005).

Despite the general acceptance that, at least in some phyla, there exists a high proportion of Antarctic marine invertebrates with pelagic development, few studies have focused on the distribution of meroplankton in the Southern Ocean. Exceptions are: a 2 yr study by Stanwell-Smith et al. (1999) at Signy Island, where 131 morphologically distinct larval forms were collected throughout the year, and a study of the distribution of pelagic larvae of benthic marine invertebrates 
in the Bellingshausen Sea, by Shreeve \& Peck (1995), in which 16 larval and juvenile types, representing 7 phyla, were reported. Very recently, Freire et al. (2006) reported seasonal variation in invertebrate larvae in Admiralty Bay in King George Island.

In addition, some other authors have described or quantified the meroplankton community - Ross Sea: Foster (1987, 1989a,b, 1991), Sewell (2005); Antartictic Peninsula, Ross Sea and Terre Adélie: Bhaud et al. (1999); eastern Antarctica: Tanimura et al. (1986); Ellis Fjord near Davis station: Kirkwood (1993).

The Bransfield Strait is a semi-enclosed Antarctic sea located between the South Shetlands Archipelago and the Antarctic Peninsula (see Fig. 1). It can be divided into 3 major basins - western, central, and easternseparated from each other by sills shallower than $1000 \mathrm{~m}$. The basic circulation pattern consists of a western inflow of relatively warm and fresh water from the Bellingshausen Sea, the Gerlache Strait and the Circumpolar Current, and an eastern inflow of relatively cold and salty water from the Weddell Sea (Grelowski et al. 1986, Hoffmann et al. 1996, García et al. 2002, Zhou et al. 2006). Following Tokarczyk (1987), Garcia et al. (1994) named these water masses as Transitional Zonal Water with Bellingshausen influence (TBW), and Transitional Zonal Water with Weddell Sea influence (TWW). TBW flows northeastwards along the northern half of the Strait whereas TWW circulates southwestwards along the southern half of the Strait. Both water masses are separated by a shallow hydrographic front. This front has also been observed in both the Western Basin (García et al. 2002) and in the Eastern Basin of the Bransfield Strait (López et al. 1999). A second front, the so-called Bransfield front, has also been observed in this region. This is a slope front that is located along the southern South Shetland Island slope and that separates TBW from the waters on the shelf of the archipelago (García et al. 1994). There is a baroclinic jet associated with this slope front, which is known as the Bransfield Current (BC) (Niiler et al. 1991, Zhou et al. 2002, Zhou et al. 2006), and which circulates northeastwards along the southern South Shetland Island slope. Zhou et al. (2006) suggested that this current could be viewed as a narrow western boundary current where a southwestward windinduced flow would return northeastwards as a consequence of the blockage in the topography.

The present study describes the vertical and horizontal distribution of the pelagic larvae of benthic marine invertebrates at 19 stations along the Bransfield Strait, Antarctica, and their relationships with hydrographical conditions. Meroplanktonic organisms are subject to passive transport processes and therefore knowledge of the hydrography of the area is required to enable interpretation of the observed distribution patterns.

\section{MATERIALS AND METHODS}

Plankton sampling. Plankton sampling was carried out along 4 transects (T), each separated by 20 nautical miles, in the Bransfield Strait (Fig. 1), between the Antarctic Peninsula and the South Shetland Islands. Sampling was carried out between 30 December 2002 and 7 January 2003, from the RV B.I.O. (Buque de Investigatión Oceanográfica) 'Hespérides', as part of a project in which the mesoscale vortices in the central basin of Bransfield Strait and the physical-biological coupling were studied. T1, T2 and T4 included 4 stations each separated by 20 nautical miles. T3 was sampled at a finer spatial scale, with 7 stations each separated by 10 nautical miles (n miles).

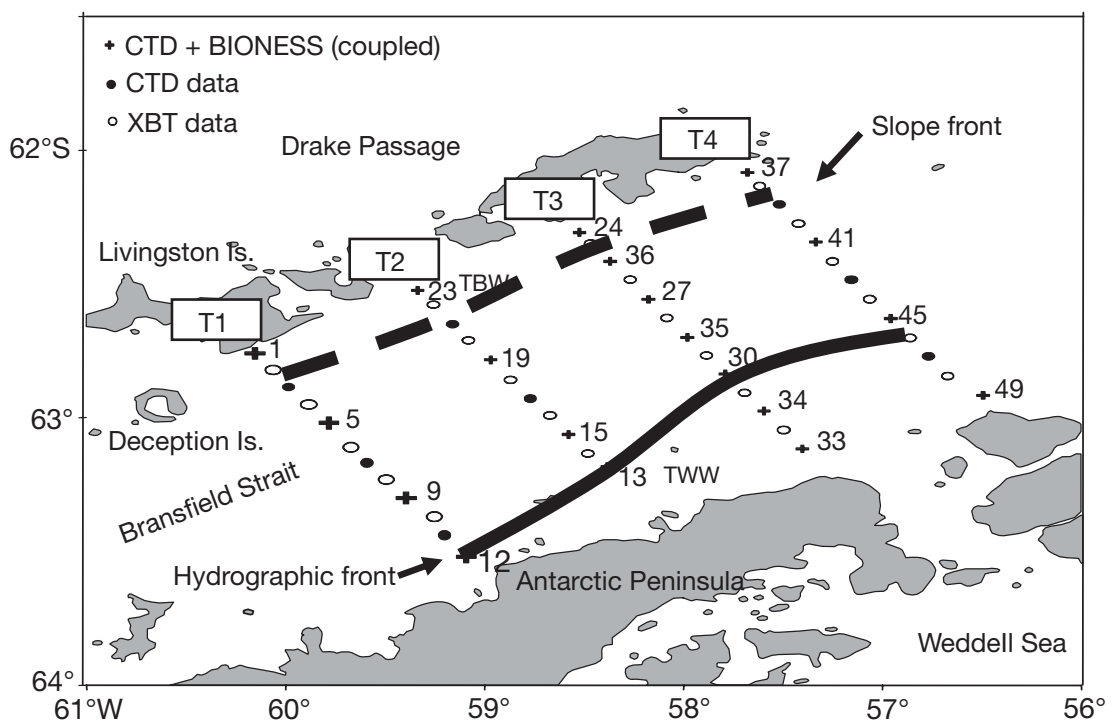

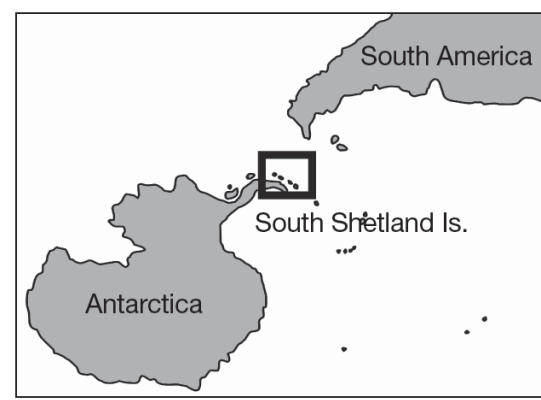

Fig. 1. Location of sampling stations in the central basin of Bransfield Strait (Antarctica), showing points of CTD and XBT (expendable bathythermograph) data collection and CTD + BIONESS ('coupled') stations (numbered). Dashed line: position of the slope front; solid line: position of the hydrographic front that separates TBW (Transitional Zonal Water with Bellingshausen influence) and TWW (Transitional Zonal Water with Weddell influence). T1-4: Transects 1-4 
The sampling gear was a multinet (BIONESS, Open Seas Instrumentation), which consists of a quadrangular $1 \mathrm{~m}^{2}$ frame with 5 double nets. Mesh sizes for the inner and outer nets (including cod ends) were $250 \mu \mathrm{m}$ and $80 \mu \mathrm{m}$, respectively. Standard procedure was to lower the net below the maximum sampling depth for the station, and to make an oblique ascending tow, opening the nets at the desired depth ranges: 300-200, 199-100, 99-70, 69-40, 39-10 m. Samples were not collected between the surface and $10 \mathrm{~m}$ because the turbulence created by the vessel could have damaged the delicate nets. Towing speed was approximately 2 knots. The mean tow duration was 5 min $48 \mathrm{~s} \pm 1 \mathrm{~min}$ $34 \mathrm{~s}$ (SE), thus approximately $250 \mathrm{~m}^{3}$ of seawater were filtered per depth interval (mean swept water volume $=252.72 \pm 61.73 \mathrm{~m}^{3} \mathrm{SE}$ ). The larval counts for each tow were therefore corrected to a standard sampling volume of $200 \mathrm{~m}^{3}$.

Hydrographic sampling. Along each transect CTD stations were combined with XBT (expendable bathythermograph) stations to obtain a $5 \mathrm{n}$ mile resolution in the temperature field and hence to resolve the spatial variability close to mesoscale, since the mesoscale in the Southern Ocean is smaller than $10 \mathrm{n}$ miles (Huntley \& Niiler 1995, Zhou et al. 2006).

The mean distance between CTD stations was $10 \mathrm{n}$ miles. At every 2nd CTD station in T1, T2, T4, and each CTD station in T3, plankton were sampled with a BIONESS multinet. These station were designated coupled stations (Fig. 1).

A Neil Brown Mark III CTD was used. Temperature and salinity were calibrated with readings from a digital reversible thermometer and with water samples in which salinity was measured with a Portasal salinometer. Temperature was accurate to $0.001^{\circ} \mathrm{C}$ and salinity to $0.003 \%$. Prior to the launching of each XBT, temperature was calibrated with the temperature reading on a digital thermometer held in a bucket of water. Several joint profiles of CTD and XBT were constructed to verify the readings registered by the XBT. The relative geostrophic velocities to 500 dbar were calculated in accordance with other studies carried out in the region (Grelowski et al. 1986, Gomis et al. 2002). Transport through the transects was also calculated by integrating geostrophic velocities from 500 dbar to the surface.

Laboratory study. Plankton samples were anaesthetised with menthol crystals in surface sea water for $4 \mathrm{~h}$ prior to fixation. The samples were fixed with $40 \%$ formaldehyde to a final concentration of $4 \%$ formalin in sea water.

The entire 176 net samples were examined under a binocular microscope, and larvae were separated from holoplankton. One of the major problems of the study of meroplankton is the identification of larvae. The taxonomic identification to species level of Antarctic marine invertebrates is problematic because the life cycles of the majority remain unknown. In the present study we therefore identified, classified and quantified larvae to high taxonomic levels.

Non-metric multidimensional scaling (MDS) was applied on the basis of the abundance of polychaete and echinoderm larvae (larvae $200 \mathrm{~m}^{-3}$ ) at each station in each water mass (TWW and TBW), so that depth layers were grouped according to the water mass where they were situated. The results were transformed by $\log (x+1)$ (to remove the bias of highly abundant taxa) before being analysed with the PRIMER statistical package.

\section{RESULTS}

\section{Hydrography}

The vertical distributions of potential temperature, salinity and density anomalies along T3 are shown in Fig. 2. The TBW was easily recognised by the well stratified, warmer and saltier water mass that lies over the homogeneous colder and saltier TWW. These water masses are separated by a $0.3^{\circ} \mathrm{C}$ isotherm, a $34.4 \mathrm{psu}$ isohaline and a $27.65 \mathrm{~kg} \mathrm{~m}^{-3}$ isopycnal. At the southern part of the transect, the TWW reaches the surface and defines a shallow hydrographic front (100 m depth) at Stn 34, which separates TBW and TWW. In the northern part of the transect at the South Shetland Islands slope, isotherms, isohalines and isopycnals show significant tilting that defines a slope front - the so-called Bransfield Front-between Stns 24 and 26 , to a depth of $400 \mathrm{~m}$.

The distributions of hydrographic properties along T1, T2, and T4 are similar to those in T3 (Fig. 2). A plot of the position of both the slope front and the hydrographic front for the 4 transects is shown in Fig. 1. In T1, TWW does not reach the surface and in T4 the hydrographic front is further north. Other studies carried out in this region have shown that TBW narrows to the northeast, with the hydrographic front closer to the South Shetland Islands in a northeast direction (Garcia et al. 1994, Basterretxea \& Arístegui 1999).

The geostrophic transport along the 4 transects from 500 dbar to the surface is shown in Fig. 3. The main feature of the transport distribution is the relatively strong and narrow transport flowing northeastwards along the South Shetlands Island slope, which gives rise to the $\mathrm{BC}$. This current originated as a baroclinic jet associated with the slope front. Surface geostrophic velocity relative to 500 dbar for the $\mathrm{BC}$ ranged from $0.17 \mathrm{~m} \mathrm{~s}^{-1}$ at T4 to $0.26 \mathrm{~m} \mathrm{~s}^{-1}$ at T3. These values are of the same order of those reported by Grewloski et al. 


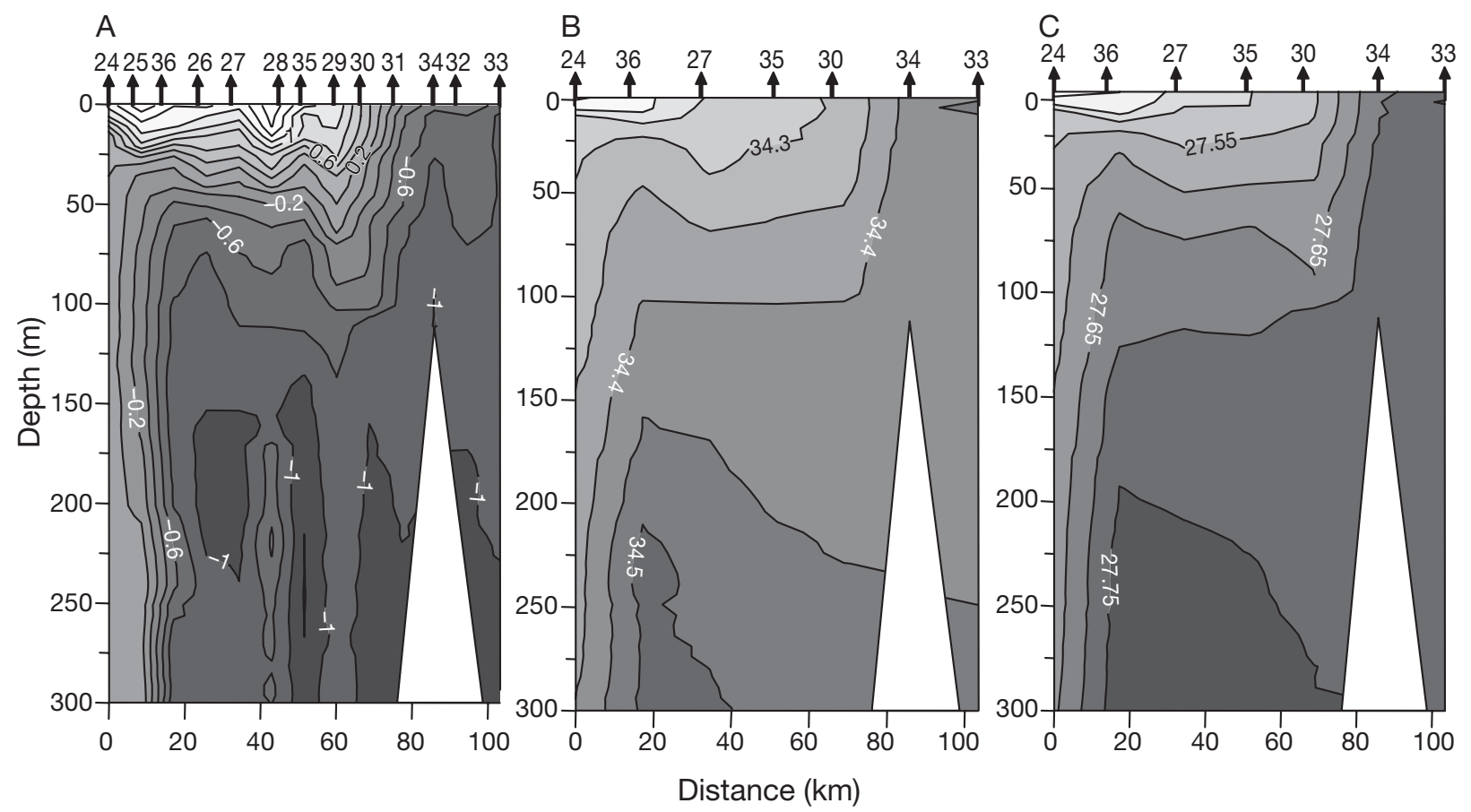

Fig. 2. XBT (expendable bathythermograph) and CTD profiles of Transect 3. Potential (a) temperature $\left({ }^{\circ} \mathrm{C}\right)$, (b) salinity (psu), and (c) density anomalies $\left(\mathrm{kg} \mathrm{m}^{-3}\right)$. Arrows: CTD stations

(1986) and Gomis et al. (2002). However the values registered by direct current acoustic Doppler current profiler (ADCP) measurement were approximately twice as high $\left(0.5 \mathrm{~ms}^{-1}\right)$ (Zhou et al. 2006). Geostrophic velocity vertical sections (not shown here) show strong vertical shears that may favour the development of mixed regions associated with the baroclinic jet. Outside the BC, transport and current are very diffuse and weak, with mean surface values as low as $0.02 \mathrm{~m} \mathrm{~s}^{-1}$

\section{Larval abundance and composition}

A total of 59521 larvae were collected during the survey. Highest larval abundances were recorded at Stn 23 on T2, with almost 30 larvae $\mathrm{m}^{-3}$ in layers from $40-70,70-100$ and 100-200 m depth (Fig. 4). In contrast, larvae were very scarce at Stns 9, 12, 13 and 15, close to the Antarctica Peninsula. Larval abundance was low in the 200 to 300 m layers, except at Stn 19 (Fig. 4).

Holoplanktonic larvae (mainly copepod nauplii, $64.9 \%$ of the total number of larvae collected, $\mathrm{n}=38542$ ) were more abundant than benthic invertebrate larvae. Never-

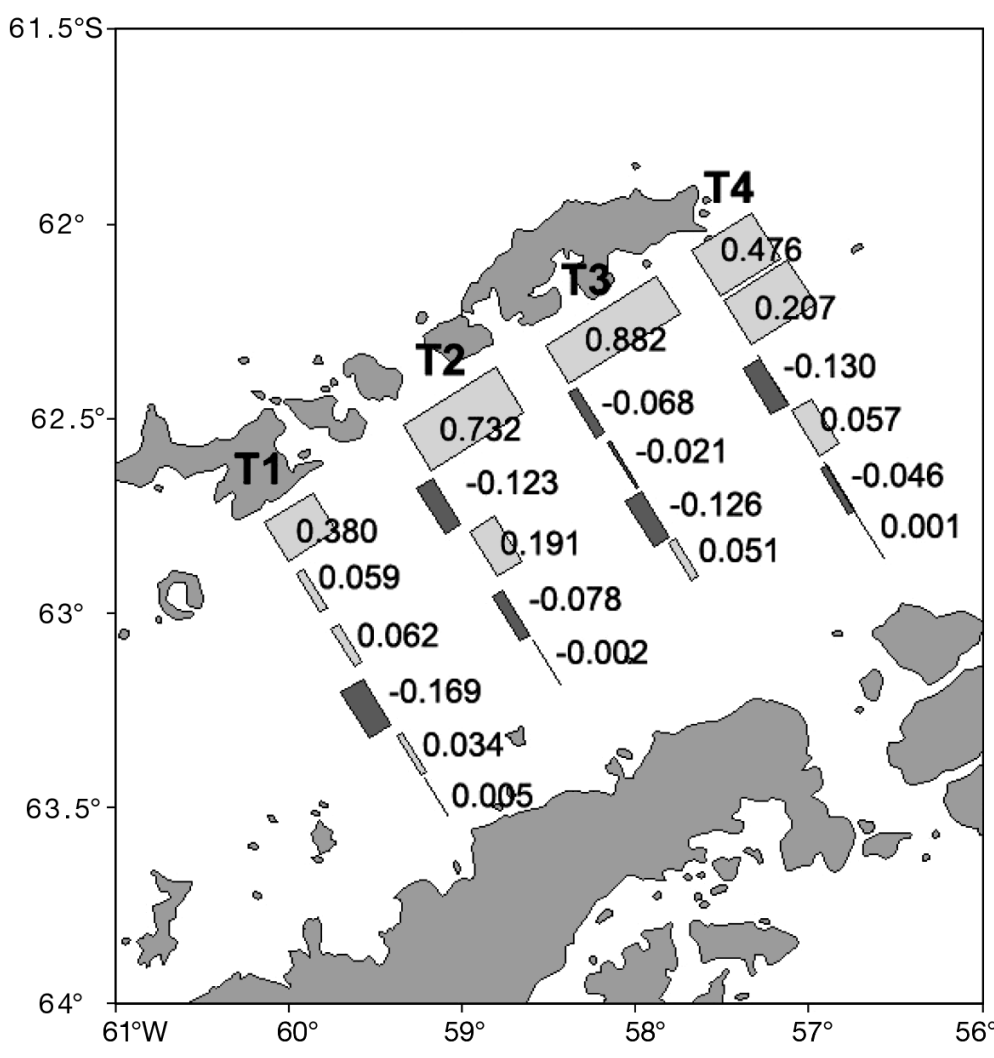

Fig. 3. Integrated geostrophic transport from 500 dbar to the surface. Dark grey bars: northeastwards (positive) transport, light grey bars: southwestwards (negative) transport; units: Sverdrups (Sv) 


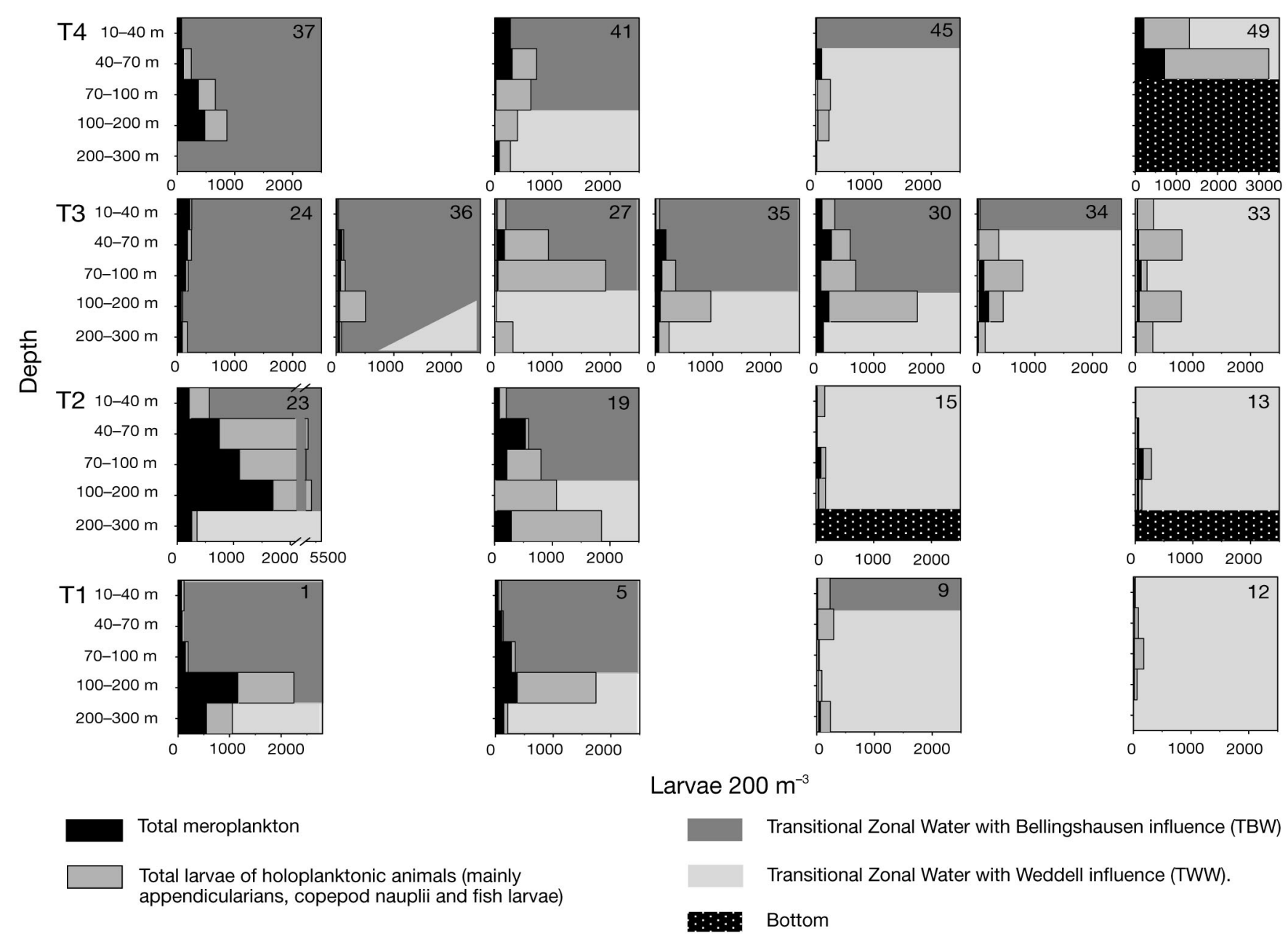

Fig. 4. Larval distribution in Bransfield Strait. Abundances are expressed as larvae $200 \mathrm{~m}^{-3}$. South Shetland Islands are to the left of panels and the Antarctic Peninsula to the right (not shown). Order of transects reflects their geographic arrangement

theless meroplankton represented $28.4 \% \quad(17211$ larvae) of the total, and were very abundant at stations close to the South Shetland Islands (Stns 1, 23, and 37).

The summer meroplankton community was dominated by polychaete larvae (mainly nectochaetes) and echinoderm larvae (mainly asteroid brachiolaria), which represented $67.4 \%(\mathrm{n}=11607)$ and $23 \%$ ( $\mathrm{n}=3947$ ) respectively of the total meroplankton. Nemertean pilidium larvae represented $2.5 \%(n=424)$ of all larvae. A total of 361 (2.1\%) cypris larvae were collected. Sipunculid pelagosphaerae ( $\mathrm{n}=203$ ), molluscan veligers $(\mathrm{n}=185)$, decapod zoea $(\mathrm{n}=109)$, enteropneustan tornariae $(n=102)$, planulae $(n=93)$, pycnogonidan protonymphons ( $\mathrm{n}=90$ ), ascidian tadpole larvae $(\mathrm{n}=85)$ and bryozoan cyphonaute larvae $(n=5)$ were considerably less abundant. The description of all these types of larvae will be published elsewhere (E. Vázquez \& J. Ameneiro unpubl.).

\section{Meroplankton distribution}

Benthic invertebrate larvae were more abundant close to the South Shetlands Islands and decreased in abundance towards the Antarctic Peninsula between the South Shetland Islands and the slope front in the TBW (Fig. 5). An increment in larval abundance with depth was observed at Stns 1, 23 and 37, and was maximal just above the end of the slope front situated between 150 and $230 \mathrm{~m}$ depth. Distribution was uniform at Stns 24 and 36, where strong mixing processes in the upper $300 \mathrm{~m}$ of the water masses occurred.

Polychaete larvae were found close to both shores but mainly near the South Shetland Islands in TBW, and reached densities of almost $10 \mathrm{~m}^{-3}$ in the 100 to 200 m layer at Stn 23 (Fig. 5). Polychaete larvae were very sparse in the central part of the Bransfield Strait and appeared below $100 \mathrm{~m}$ depth in TWW (Fig. 5). A 

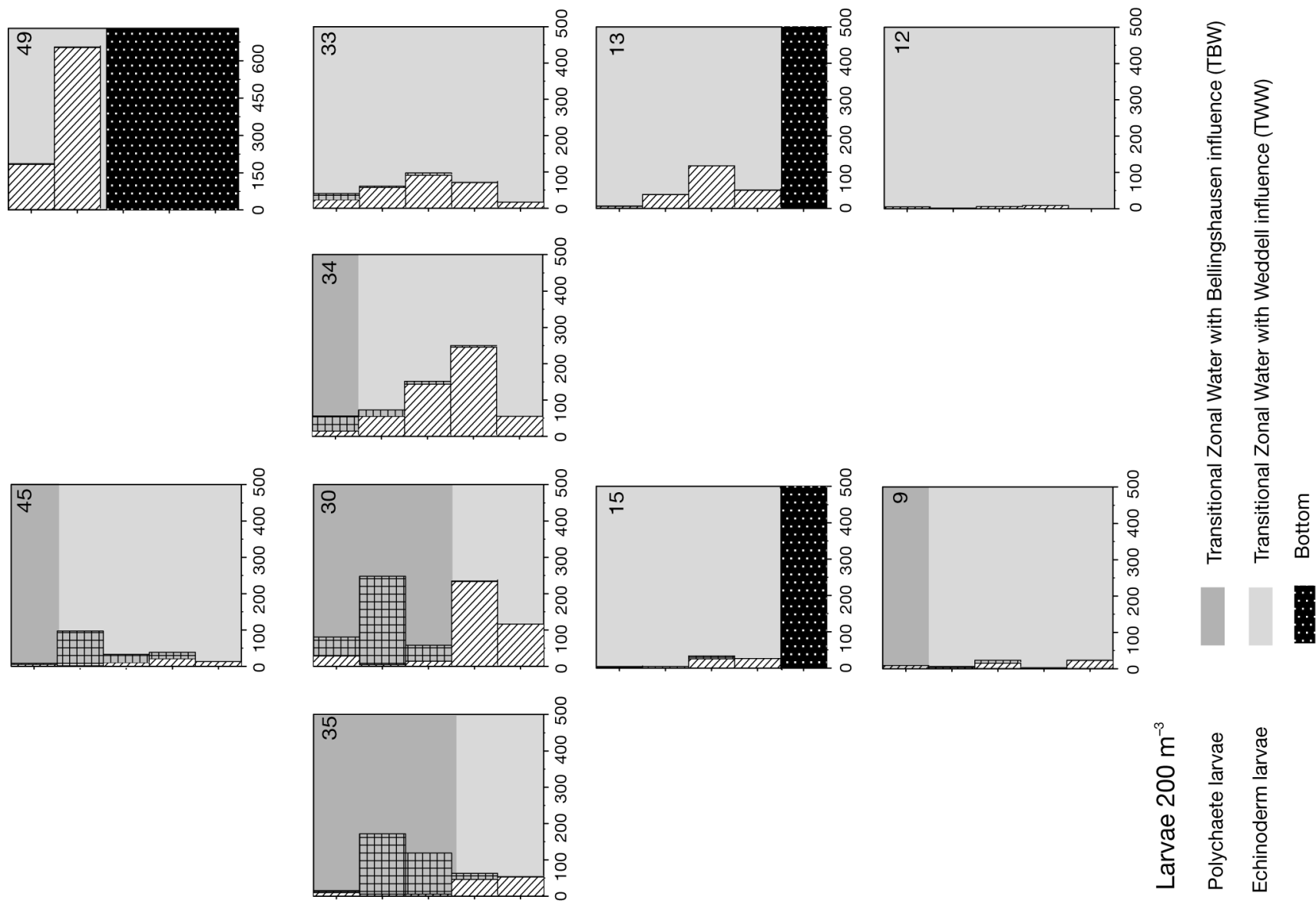

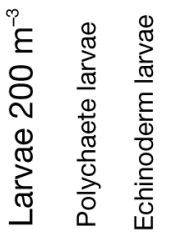
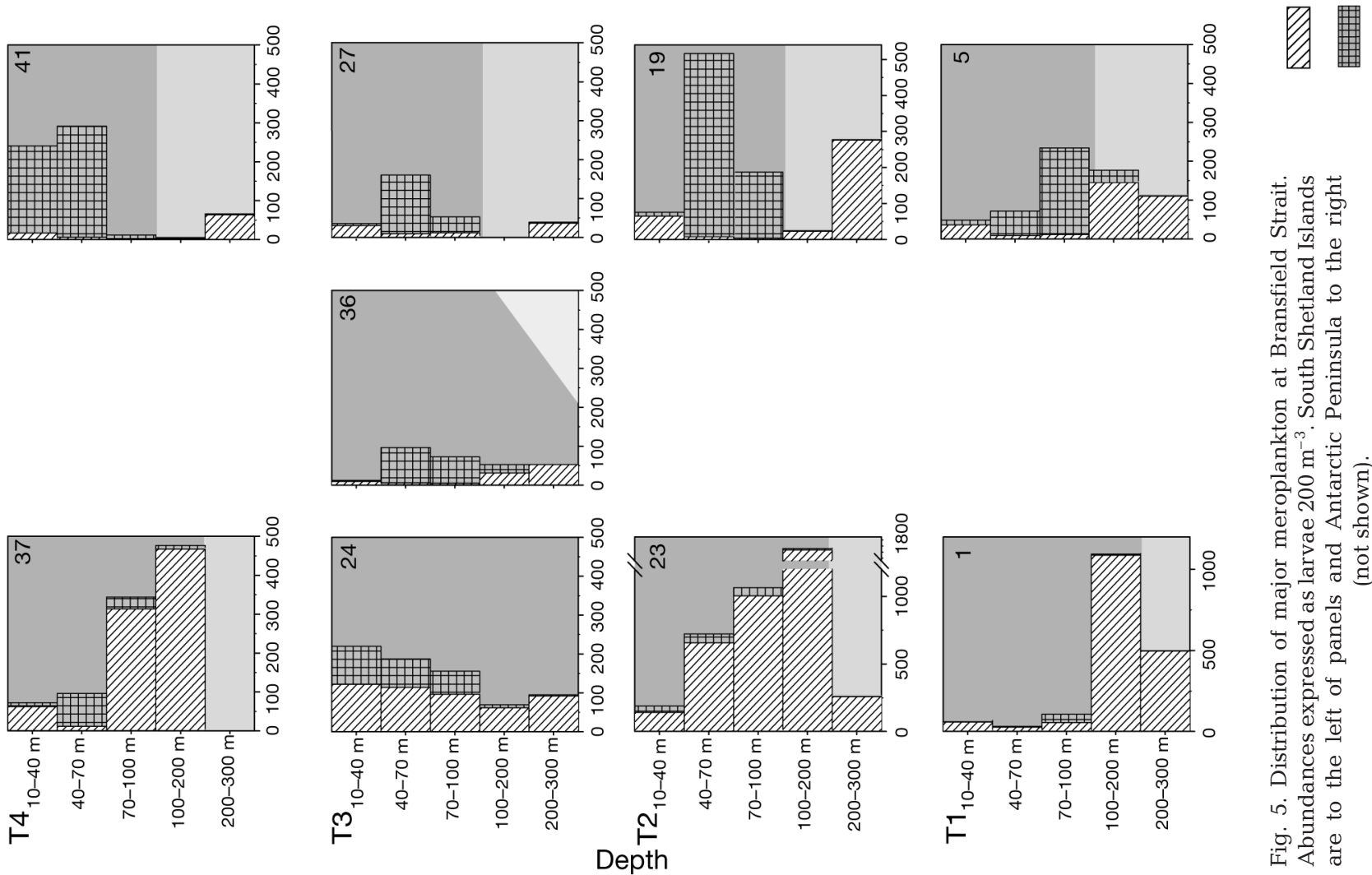
slight increase in abundance in the upper layers at stations between the hydrographic front and the Antarctic Peninsula, in TWW, was observed.

Echinoderm larvae were the second most abundant type of larvae. They mainly occupied the central part of the Bransfield Strait and reached densities of $6 \mathrm{~m}^{-3}$ between 40 and $70 \mathrm{~m}$ depth at $\mathrm{Stn} 19$. The larvae always appeared in the upper $100 \mathrm{~m}$ of the water column in TBW, just above the polychaete larvae (Fig. 5). They were almost absent at stations and depths characterized by TWW.

The MDS ordination analysis of abundances of echinoderm and polychaete larvae (Fig. 6) revealed 6 major assemblages. The first (Fig. 6a) comprised the upper layers that corresponded to TBW of stations located in the central basin of the Bransfield Strait and were characterized by high abundances of echinoderm larvae. The second group (Fig. 6b) was formed by layers in TBW of the 4 stations located in the BC close to the South Shetland Islands defined by a high abundance of polychaete larvae; in addition the TWW layers of Stns 5 and 34 were also included here because of the large number of polychaete larvae that they contained. The other 4 groups (Fig. 6c-f) included stations and layers of stations in TWW characterized by a gradient from high (Fig. 6c) to low (Fig. 6f) polychaete abundance.

Although larvae of other benthic animals were less abundant, their distributions were very distinctive (Fig. 7). Ascidian larvae were mainly found in TWW in the stations between the hydrographic front and

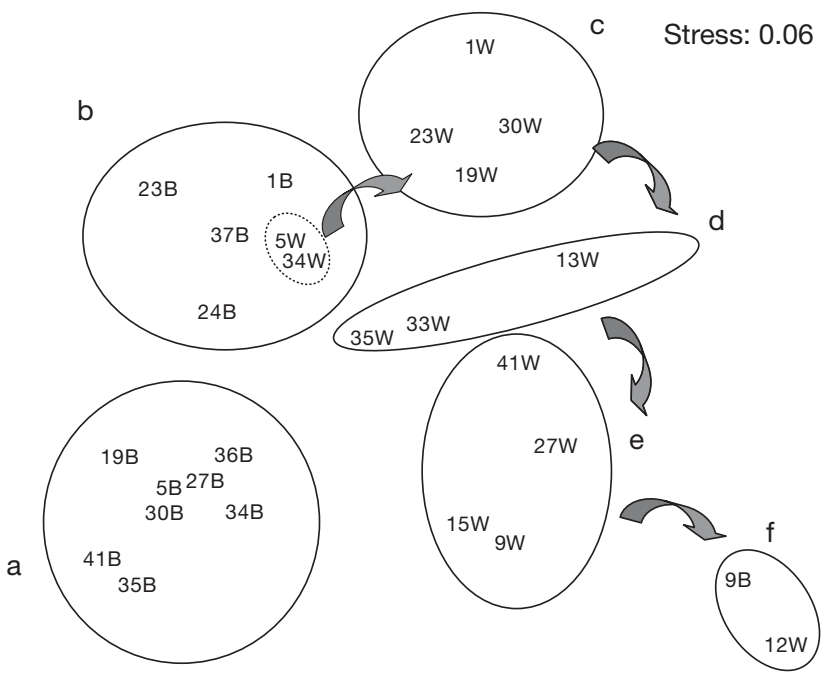

Fig. 6. MDS ordination analysis of the stations on the basis of abundances of echinoderm and polychaete larvae. (a-f) Major assemblages (see 'Meroplankton distribution' in 'Results' for more details). Number of station indicates depth layer. B: Transitional Zonal Water with Bellingshausen influence, W: Transitional Zonal Water with Weddell influence; arrows: decreasing polychaete larval abundance
Antarctic Peninsula, and reached maximal density (38.1 larvae $200 \mathrm{~m}^{-3} ; \mathrm{n}=48$ out of 85 found in the whole survey) between 40 and $70 \mathrm{~m}$ depth at Stn 49 close to d'Urville Island. Decapod crustacean zoea larvae reached highest densities at Stn 30 and inhabited the entire water column; this station was situated close to the hydrographic front. Zoeae were also found, in lower numbers, at Stns 34 and 33 in the TWW in T3. Nemertean and cirriped larvae were concentrated in the central southern part of Bransfield Strait. In contrast, sipunculid pelagosphaera larvae were very uniformly distributed throughout the Bransfield Strait below $100 \mathrm{~m}$ depth. Gastropod veligers were also uniformly distributed, mainly in the central part of the Bransfield Strait and were very sparse close to the South Shetlands Islands.

\section{DISCUSSION}

As far as we know this is the first study of invertebrate larval distribution in Antarctic waters with a $80 \mu \mathrm{m}$ mesh plankton net with high vertical (5 depth layers from 10 to $300 \mathrm{~m}$ ) and horizontal (19 stations in 120 square $\mathrm{n}$ miles) resolution. In previous studies (Shreeve \& Peck 1995, Bhaud et al. 1999, StanwellSmith et al. 1999, Absher et al. 2003) nets of 100 to $200 \mu \mathrm{m}$ mesh size were used at a maximum of 3 depth horizons.

\section{Meroplankton abundance and composition}

References to the scarcity of marine invertebrate larvae in Antarctic waters date from the first expeditions to the Southern Ocean (reviewed in Arntz \& Gili 2001) and were confirmed recently (Shreeve \& Peck 1995, Stanwell-Smith et al. 1999, Sewell 2005). Although quantitative comparison of larval numbers is difficult due to differences in the sampling gear used, depth of sampling, and particularly in relation to plankton and mesh size, the present results corroborate the paucity of invertebrate larvae in Antarctica.

The abundance of meroplankton in the Bransfield Strait was very variable, and depended on depth and geographical location. Maximum abundance was 8.43 benthic invertebrate larvae $\mathrm{m}^{-3}$ in the 100 to $200 \mathrm{~m}$ layer at Stn 23. This is within the range of densities reported by other authors in other Antarctic locations, although far from figures given for fjord systems and enclosed bays where retention of larvae can occur (Sewell 2005) (Table 1). Timing of sampling is also important. Studies carried out throughout the entire year showed larval peaks between mid and late January (Tanimura et al. 1986, Kirkwood 1993) and in Feb- 

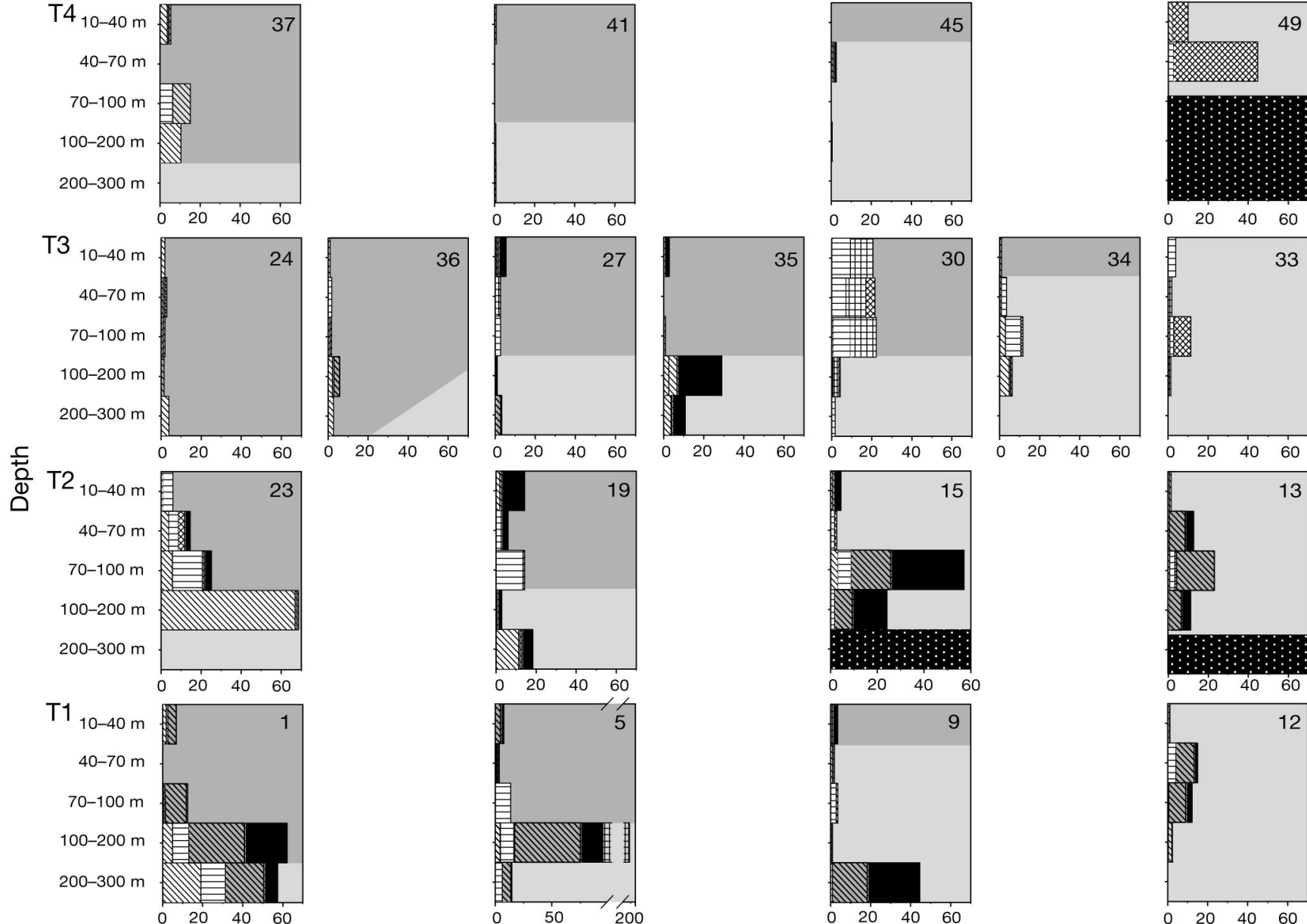

Larvae $200 \mathrm{~m}^{-3}$
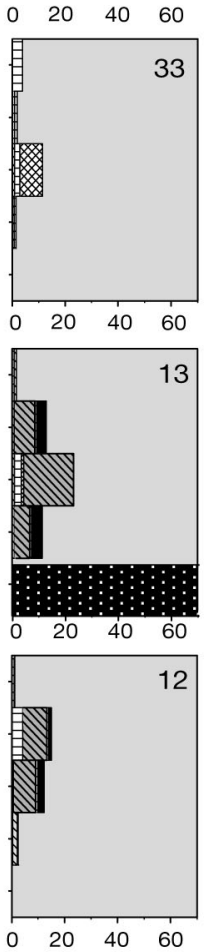

NIIV Pelagosphaera larvae

Veliger larvae

Zoea larvae

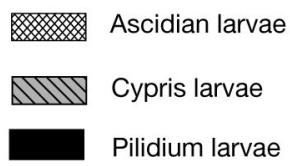

Transitional Zonal Water with Weddell influence (TWW).

Transitional Zonal Water with Bellingshausen influence (TBW)

Bottom

Fig. 7. Distribution of minor meroplankton at Bransfield Strait. Abundances expressed as larvae $200 \mathrm{~m}^{-3}$. South Shetland Islands are to the left and Antarctic Peninsula to the right (not shown).

ruary-March (Stanwell-Smith et al. 1999, Freire et al. 2006) (Table 1). The present study and those by Shreeve \& Peck (1995) and Sewell (2005) (Table 1) were undertaken before the peak levels were reached.

However the scarcity of benthic marine invertebrate larvae in the Southern Ocean refers to abundances rather than to species/larval type richness, as has been demonstrated in recent years (Stanwell-Smith et al. 1999, Sewell 2005, present study). Several explanations for the paucity of benthic invertebrate larvae have been proposed. One such idea is that direct development is the predominant reproductive strategy in deep waters, because of the limited availability of food (e.g. Thorson 1950, Mileikovsky 1971). Neverthe- less, the validity of this hypothesis, known as 'Thorson's rule', has been questioned as more Antarctic investigations are carried out (see Arntz \& Gili 2001).

The reduction in intertidal and shallow subtidal species due to effects exerted by ice has also been postulated as a major factor explaining the lower larval numbers relative to temperate latitudes (Shreeve \& Peck 1995). These authors also pointed out the long distances offshore (300 and $600 \mathrm{~km}$ ) of their survey to explain the low larval numbers and suggested that similar investigations closer inshore may reveal higher numbers of larvae. We have found similar larval abundances in the Bransfield Strait at stations close to shore in the South Shetland Islands and much lower abun- 
Table 1. Meroplankton abundance in different locations in Antarctica with the maximum peak of abundance in year-round surveys

\begin{tabular}{|lclll|}
\hline Location & Abundance $\left(\mathrm{m}^{-3}\right)$ & Max. peak & Survey period & Source \\
\hline $\begin{array}{l}\text { Signy Island, } \\
\text { South Orkney Islands }\end{array}$ & 2.74 & $\begin{array}{l}\text { Feb-Mar } \\
\text { Jul-Sep }\end{array}$ & 2 yr & Stanwell-Smith et al. (1999) \\
$\begin{array}{l}\text { McMurdo Sound, Ross Sea } \\
\text { Bransfield Strait }\end{array}$ & 3 & & Late Nov-early Dec & Sewell (2005) \\
$\begin{array}{l}\text { Admiralty Bay, } \\
\text { King George Island }\end{array}$ & 8.43 & March & Early January & Present study \\
$\begin{array}{l}\text { Bellingshausen Sea } \\
\text { Syowa Station, }\end{array}$ & 15 & & Nov-Day & Freire et al. (2006) \\
$\quad$ Ongul Island & 220 & Late Jan & 1 yr & Shreeve \& Peck (1995) \\
Ellis Fjord & 228 & Mid Jan & $1 \mathrm{yr}$ & Tanimura et al. (1986) \\
\hline
\end{tabular}

dances at stations close to the Antarctic Peninsula shore. Distance to shore does not therefore appear to explain low densities. In fact lower densities than those reported by Shreeve \& Peck (1995) and in the present study were reported for sublittoral locations between 6 and $28 \mathrm{~m}$ depth (Stanwell-Smith et al. 1999).

Another explanation for the low densities is related to the timing of gamete/larval release and developmental rates. The Southern Ocean is characterized by a year-round but low abundance of long-lived, slowdeveloping larvae rather than by large pulses of larvae (Stanwell-Smith et al. 1999). Studies of developmental rates have shown that low temperature can increase the development time by as much as 20-fold (Bosch et al. 1987, Peck \& Robinson 1994). These factors result in much-extended pelagic developmental periods and therefore potentially long-distance dispersal and dilution in the water column.

On the basis of a small number of studies carried out on Antarctic meroplankton, 3 meroplanktonic communities can be distinguished. In open waters, meroplankton are dominated by a mass occurrence of polychaete larvae followed by echinoderm and nemertean larvae, as described for the Bellingshausen Sea (Shreeve \& Peck 1995) and the Bransfield Strait (present study). Polychaete larvae were also the most abundant meroplanktonic group in shallow coastal waters - as in Signy Island, South Orkney Islands (Stanwell-Smith et al. 1999); Ongul Island, Eastern Antarctic (Tanimura et al. 1986); Ross Island, Ross Sea (Sewell 2005) — with molluscan veliger larvae being the second most abundant and echinoderm larvae being found in low numbers. Finally, the only 2 semienclosed hydrographic environments studied so far differ in composition. In Admiralty Bay, King George Island, molluscan veligers represented $80 \%$ of total meroplankton whereas polychaete larvae were less abundant ( 7 to $11 \%$ ) followed by echinoderm and nemertean larvae, and in Ellis Fjord echinoderm and ascidian larvae were the most abundant types of larvae
(Kirkwood 1993). Larvae may be retained in these habitats (Sewell 2005) and the local benthic population probably establishes the community.

\section{Coupling oceanography and meroplankton distribution}

Contrary to the findings of Stanwell-Smith et al. (1999) for Signy Island, i.e. that most of the variability in the larval abundance was attributable to seasonality rather than to site or depth effects because the long larval life ensured mixing within sites, we found that the presence of meroplanktonic larvae was closely related to depth, water masses and fronts. Currents may generally enhance larval dispersal but also create physical barriers such as density gradients or mixing zones, which restrict the spread of larvae (Scheltema 1986).

Meroplankton were more abundant in TBW and decreased towards the continent where cold water of Weddell origin (TWW) runs parallel to the Antarctic Peninsula. Larval abundance increased with depth to the discontinuity between TBW and TWW at approximately 200 m, and then decreased. Stns 24 and 36 were exceptions to this finding as larvae were uniformly distributed, probably because of strong mixing processes related to the strong shear associated with the BC.

Polychaete larvae were mainly found between the South Shetland Islands and the Bransfield Front in warm water of Bellingshausen origin (TBW). They were sparse in the central part of the Bransfield Strait, where they appeared below $100 \mathrm{~m}$ depth, and increased in abundance again between the hydrographic front and the Antarctic Peninsula, in TWW. Meroplanktonic larvae are generally weak swimmers and their dispersal depends on the distribution of adults and the prevailing hydrodynamics (Pedotti \& Fenaux 1992). We speculated 2 different origins for these polychaete larvae. Those in TBW may originate from the abundant adult populations of sedentary 
polychaetes living close to the South Shetland Islands (Arnaud et al. 1998). Those in TWW may originate close to the Antarctic Peninsula and be distributed into the whole water column close to the peninsula but sinking below $100 \mathrm{~m}$ under the warmer and lower salinity TBW in the central part of Bransfield Strait. An attempt to identify these larvae was undertaken to clarify this point (E. Vázquez \& J. Ameneiro unpubl.).

Echinoderm larvae mainly occupied the shallowest layers of the central part of the Bransfield Strait in the TBW, and attained densities of $6 \mathrm{~m}^{-3}$. They always appeared in the upper $100 \mathrm{~m}$ of the water column just above the TWW, which confirms the pelagic habitat of the echinoderm larvae (Pearse \& Bosch 1986, Shreeve \& Peck 1995). These larvae may originate from the large biomass of Asteroidea, Echinoidea Regularia and Ophiuroidea (Arnaud et al. 1998) that inhabit the benthos in this region. Preliminary results revealed that these larvae may be associated with maximum fluorescence (E. Vázquez \& L. Lubián unpubl.).

Ascidian larvae were mainly found in TWW, reaching highest densities at between 40 and $70 \mathrm{~m}$ depth closest to the shore and at the shallowest station close to habitats where adult populations dominate, i.e. above $100 \mathrm{~m}$ depth with strong glacier influence as in the shores of Antarctic Peninsula (Sáiz-Salinas et al. 1997, Sahade et al. 1998). The low transport $(0.001 \mathrm{~Sv})$ recorded at this station may retain larvae close to adult populations.

In summary, meroplankton distribution in the Bransfield Strait appears to be the product of adult spawning and hydrography. Spawning by adults establishes the initial distribution of eggs and larvae, but the local hydrographic conditions may determine larval dispersal.

Acknowledgements. This manuscript is a result of the BREDDIES Project (REN2001-2650/ANT) sponsored by the Spanish Ministry of Science and Technology. We thank Dr. J. Bellas, G. Macho and C. Martínez for their field assistance, and all scientists participating in the BREDDIES survey for their support. Thanks also to the officers, crew and Unidad de Tecnología Marina (UTM) technicians of RV 'Hespérides' for their invaluable help. D. Wellwood (Open Seas Instrumentation) helped with net design.

\section{LITERATURE CITED}

Absher TM, Boehs G, Feijó AR, da Cruz AC (2003) Pelagic larvae of benthic gastropods from shallow Antarctic waters of Admiralty Bay, King George Island. Polar Biol 26: 359-364

Arnaud PM, López CM, Olaso I, Ramil F, Ramos-Esplá AA, Ramos A (1998) Semi-quantitative study of macrobenthic fauna in the region of the South Shetland Islands and the Antarctic Peninsula. Polar Biol 19:160-166

Arntz WE, Gili JM (2001) A case for tolerance in marine ecology: let us not put out the baby with the bathwater. Sci Mar 65(Suppl 2):283-299
Basterretxea G, Arístegui J (1999) Phytoplankton biomass and production during late austral spring (1991) and summer (1993) in the Bransfield Strait. Polar Biol 21: $11-22$

Bhaud M, Koubbi P, Razouls S, Tachon O, Accornero A (1999) Description of planktonic polychaete larvae from Terre Adélie and the Ross Sea (Antarctica). Polar Biol 22: 329-340

Bosch I, Beaucham KA, Steel ME, Pearse JS (1987). Development, metamorphosis, and seasonal abundance of embryos and larvae of the Antarctic sea urchin Sterechinus neumayeri. Biol Bull 173:126-135

Foster BA (1987) Composition and abundance of zooplankton under the spring sea-ice of McMurdo Sound. Polar Biol 8:41-48

Foster BA (1989a) Time and depth comparisons of sub-ice zooplankton in McMurdo Sound. Polar Biol 9:431-435

Foster BA (1989b) Balanomorph barnacle larvae in the plankton at McMurdo Sound. Polar Biol 10:175-177

Foster BA (1991) Zooplankton comparisons in McMurdo Sound. NZ Antarct Rec 11:36-47

Freire AS, Absher TM, Cruz-Kaled AC, Kern Y, Elbers KL (2006) Seasonal variation of pelagic invertebrate larvae in the shallow Antarctic waters of Admiralty Bay (King George Island). Polar Biol 29:294-302

García MA, López O, Sospedra J, Espino M and 6 others (1994) Mesoscale variability in the Bransfield Strait region (Antarctica) during Austral summer. Ann Geophys 12(9): 856-867

García MA, Castro CG, Ríos AF, Doval MD, Rosón G, Gomis D, López O (2002) Water masses and distribution of physico-chemical properties in the Western Bransfield Strait and Gerlache Strait during Austral summer 1995/96. Deep-Sea Res II 49:585-602

Gomis D, García MA, López O, Pascual A (2002) Quasigeostrophic 3D circulation and mass transport in the western of the South Shetland Islands. Deep-Sea Res II 49: 603-621

Grelowski A, Majewicz A, Pastuszack M (1986) Mesoscale hydrodynamic processes in the region of the Bransfield Strait and the southern part of the Drake Passage during BIOMASS-SIBEX 1983/84. Pol Polar Res 7:353-369

Hoffmann EE, Klinck JM, Lascara CM, Smith DA (1996) Water mass distribution and circulation west of the Antarctic Peninsula and including Bransfield Strait. In: Ross R, Hofmann E, Quetin L (eds) Antarctic Research Series, Vol 70. American Geophysical Union, Washington, DC, p 61-80

Huntley ME, Niiler PP (1995). Physical control of population dynamics in the Southern Ocean. ICES J Mar Sci 52: 457-468

Kirkwood JM (1993) Zooplankton community dynamics and diel vertical migration in Ellis Fjord, Vestfold Hills Antarctica. PhD thesis, Monash University, Melbourne

López O, García MA, Gomis D, Rojas P, Sospedra J, SánchezArcilla A (1999). Hydrographic and hydrodynamic characteristics of the eastern basin of the Bransfield Strait (Antarctica). Deep-Sea Res I 46:1755-1778

Mileikovsky SA (1971) Types of larval development in marine bottom invertebrates, their distribution and ecological significance: a re-evaluation. Mar Biol 10:193-213

Niiler P, Amos A, Hu JH (1991) Water masses and $200 \mathrm{~m}$ relative geostrophic circulation in the western Bransfield Strait region. Deep-Sea Res 38:943-959

Pearse JS, Bosch I (1986) Are the feeding larvae of the commonest Antarctic asteroid really demersal? Bull Mar Sci 39:477-484 
Peck LS, Robinson K (1994) Pelagic larval development in the brooding Antarctic brachiopod Liothyrella uva. Mar Biol 120:279-286

Pedotti ML, Fenaux L (1992) Dispersal of echinoderm larvae in a geographical area marked by upwelling (Ligurian Sea, NW Mediterranean). Mar Ecol Prog Ser 86:217-227

Poulin E, Palma AT, Féral JP (2002) Evolutionary versus ecological success in Antarctic benthic invertebrates. Trends Ecol Evol 17(5):218-222

Sahade RJ, Tatian M, Kowalke J, Kuhne S, Esnal GB (1998) Benthic faunal associations on soft substrates at Potter Cove, King George Island, Antarctica. Polar Biol 19: 85-91

Sáiz-Salinas JI, Ramos A, García FJ, Troncoso JS, San Martín G, Sanz C, Palacín C (1997) Quantitative analysis of macrobenthic soft-bottom assemblages in South Shetland waters (Antarctica). Polar Biol 17:393-400

Scheltema RS (1986) Long distance dispersal by planktonic larvae of shoal-water benthic invertebrates among Central Pacific islands. Bull Mar Sci 39:241-256

Sewell M (2005) Examination of the meroplankton community in the south-western Ross Sea, Antarctica, using a collapsible plankton net. Polar Biol 28:119-131

Shreeve RS, Peck LS (1995) Distribution of pelagic larvae of

Editorial responsibility: Otto Kinne (Editor-in-Chief),

Oldendorf/Luhe, Germany benthic marine invertebrates in the Bellingshausen Sea. Polar Biol 15:369-374

Stanwell-Smith D, Peck LS, Clarke A, Murray AWA, Todd CD (1999). The distribution, abundance and seasonality of pelagic marine invertebrate larvae in the maritime Antarctic. Philos Trans R Soc Lond B 354:471-484

Tanimura A, Fukuchi M, Hoshiai T (1986) Seasonal change in the abundance of zooplankton and species composition of copepods in the ice-covered sea near Syowa station, Antarctica. Mem Natl Inst Polar Res (Spec Issue) 40: $212-220$

Thorson G (1950) Reproduction and larval ecology of marine bottom invertebrates. Biol Rev 25:1-45

Tokarczyk R (1987) Classification of water masses in the Bransfield Strait and Southern part of the Drake Passage using a method of statistical multidimensional analysis. Pol Polar Res 8:333-336

Zhou M, Niiler PP, Hu JH (2002) Surface currents in the Bransfield and Gerlache Straits, Antarctica. Deep-Sea Res I 49:267-280

Zhou M, Niiler PP, Zhu Y, Dorland RD (2006) The western boundary current in the Bransfield Strait, Antarctica. Deep-Sea Res I 53:1244-1252

Submitted: June 8, 2006; Accepted: March 8, 2007 Proofs received from author(s): May 7, 2007 